\title{
TERAPI SPRITUAL EMOTIONAL FREDOOM TECHNIQUE MENGURANGI DEPRESI PADA PASIEN DIABETES MILLITUS
}

\author{
Nurbani*, Lily Yuniar \\ Jurusan Keperawatan Singkawang, Poltekkes Kemenkes Pontianak, J1. Dr. Sutomo No.46, Pasiran, Singkawang \\ Bar., Kota Singkawang, Kalimantan Barat, Indonesia 79123 \\ *nurbani601@gmail.com
}

\begin{abstract}
ABSTRAK
Depresi pada diabetes mellitus tipe 2 lebih umum pada: wanita, ras minoritas, seseorang yang tidak menikah di usia paruh baya, status sosial, ekonomi rendah dan tidak bekerja. Kurangnya perhatian pada kondisi ini seharusnya tidak terjadi, untuk itu kita memerlukan metode psikoterapi untuk membantu pasien diabetes mellitus dalam menangani depresi.Banyak metode psikoterapi yang bisa digunakan, salah satunya adalah teknik kebebasan emosional spiritual. Tujuan dari penelitian ini adalah untuk mengidentifikasi pemberian terapi Spiritual Emotional Fredoom Technique (SEFT) untuk mengurangi tingkat depresi pada pasien diabetes militus di Wilayah Kerja Pusat Kesehatan Singkawang Barat pada tahun 2018. Desain penelitian ini adalah eksperimen semu dengan pre dan post test tanpa kontrol. Hipotesis yang digunakan adalah Ha yaitu Intervensi Teknik Spiritual Emotional Freedom (SEFT) untuk mengurangi tingkat depresi pada pasien Diabetes Millitus, instrument pengumpulan data menggunakan dengan Beck Depression Inventory yang sudah dimodifikasi. Hasil penelitian ini adalah karakteristik responden sebagian besar responden berusia 40-60 tahun 17 responden (68\%), mayoritas adalah responden perempuan 17 responden (68\%), bekerja sebagai ibu rumah tangga 13 responden (52\%), pendidikan Responden SMA 9 (36\%) dan sebagian besar responden menderita DM selama <5 tahun sebanyak 15 responden $(60 \%)$. Hasil penelitian menunjukkan perbedaan nilai antara sebelum dan sesudah melakukan terapi Spiritual Emotion Freedom Technique (SEFT) untuk responden yang dilakukan dengan Wilcoxon Test menghasilkan nilai probabilitas 0,000 (nilai $p>0,05$ ), yang menunjukkan perbedaan yang signifikan antara sebelum dan sesudah perawatan pada pasien diabetes mellitus. Penelitian ini menunjukkan bahwa pemberian terapi SEFT dapat mengurangi depresi pada pasien dengan diabetes mellitus di wilayah Puskesmas Singkawang Barat.
\end{abstract}

Kata kunci: depresi, diabetes millitus, teknik kebebasan emosional spiritual

\section{FREDOOM THERAPY SPRITUAL THERAPY THERAPY REDUCES DEPRESSION IN DIABETES MILLITUS PATIENTS}

\begin{abstract}
It turns out that depression in type 2 diabetes mellitus is more common in: women, racial minorities, someone who is not married in middle age, social status, low economy and not work. Lack of attention to this condition should not occur, for that we need a method of psychotherapy to help patients with diabetes mellitus in dealing with depression. Many psychotherapy methods that can be used, one of which is the spiritual emotional freedom technique. The purpose of this study was to identify the provision of Spiritual Emotional Fredoom Technique (SEFT) therapy to reduce levels of depression in diabetes millitus patients in the Working Area of Singkawang Barat Health Center in 2018. The design of this study is a quasi experiment with pre and post test without control. The hypothesis used is Ha namely the Intervention of Spiritual Emotional Freedom Technique (SEFT) to reduce the level of depression in Diabetes Millitus patients. The results of this study are the characteristics of the respondents most of the respondents aged 40-60 years 17 respondents (68\%), the majority are female respondents 17 respondents (68\%), work as housewives 13 respondents (52\%), education SMA 9 respondents (36\%) and most of the respondents suffered from DM for $<5$ years as many as 15 respondents (60\%). The results showed differences in values between before and after conducting Spiritual Emotion Freedom Technique (SEFT) therapy for respondents conducted with the Wilcoxon Test resulting in a probability value of 0,000 ( $p$ value > 0.05), which indicates a significant difference between before and after treatment in diabetes mellitus patients. The conclusion from the above research shows that the administration of SEFT therapy can reduce depression in patients with diabetes mellitus in the area of Singkawang Barat Health Center in 2018 and it is recommended that psychotherapy is needed by patients experiencing psychosocial problems due to physical illness, one of which is depression.
\end{abstract}


Keywords: depresi, diabetes millitus, spiritual emaotional freedom technique

\section{PENDAHULUAN}

Sehat menurut WHO (World Health Organisation)merupakan suatu keadaan sejahtera yang meliputi fisik, mental, sosial yang tidak hanya bebas dari penyakit atau kecacatan. Kesehatan jiwa bukan hanya sekedar bebas dari gangguan tetapi lebih kepada perasaan sehat, sejahtera, dan bahagia, ada keserasian antara pikiran, perasaan, perilaku, dapat merasakan kebahagiaan dalam sebagian besar kehidupannya serta mampu mengatasi tantangan hidup sehari-hari(WHO, 2013). Saat ini gaya hidup masyarakat perkotaan semakin maju, perkembangan ekonomi maju dan penyakitpenyakit karena gaya hidup seperti penyakit tidak menular semakin meningkat.

Berdasarkan data dari WHO (2011), kematian akibat penyakit tidak menular sekitar $60 \%$ dari seluruh penyebab kematian di negara-negara berkembang. Di Indonesia, data RISKESDAS (Riset Kesehatan Dasar, 2013) menyebutkan, $60 \%$ kematian diakibatkan oleh penyakit degeneratif, dengan tiga urutan penyakit tertinggi, yaitu stroke $26,9 \%$, darah tinggi 12,3\%, dan diabetes 10,2\%(Dinas Kesehatan Republik Indonesia, 2013).

Data statistik organisasi WHO tahun 2011 menyebutkan Indonesia menduduki rangking ke 4 jumlah penyandang Diabetes Melitus terbanyak setelah Amerika Serikat, China, India(WHO, 2011). Berdasarkan data dari badan pusat statistik BPS jumlah penyandang Diabetes Melitus tahun 2003 sebanyak 13,7 juta orang, dan berdasarkan penambahan penduduk diperkirakan pada tahun 2030 memprediksikan kenaikan jumlah penyandang Diabetes Melitus di Indonesia 8,4 juta pada tahun 2000 menjadi sekitar 21,3 pada tahun 2030.. Seseorang yang menderita penyakit Diabetes Melitus dengan kadar gula yang tinggi jika tidak segera ditangani akan menyebabkan terjadinya komplikasi pada organ tubuh seperti mata, ginjal, jantung pembuluh darah dan saraf. Komplikasi yang ditimbulkan bersifat akut dan kronis, komplikasi akut terjadi penurunan atau peningkatan kadar glukosa darah secara tibatiba, sedangkan Komplikasi kronik adanya efek peningkatan kadar glukosa darah dalam jangka lama. Komplikasi tersebut akan membahayakan jiwa maupun kualitas hidup pasien serta dapat mempengaruhi usia harapan hidup pasien Diabetes melitus.

PenelitianSemenkovichmeunjukan bahwa satu dari setiap empat orang yang menderita diabetes mellitus tipe II juga menderita depresi. Faktor pencetus terjadinya distress pada penderita dikarenakan kurangnya dukungan sosial, penolakanakan keadaan yang dialaminya. Hal ini yang memunculkan rasa depresi pada penderita diabetes mellitus tipe 2 sebagai respon rasa kehilangan dan berduka yang dialaminya. Selain itu, depresi yang dialami oleh penderita diabetes mellitus tipe 2 dapat meningkatkan resiko komplikasi pada diabetes mellitus tipe II itu sendiri seperti, hiperglikemia, insulin, resistensi, dan mikro dan makrovaskuler. Sebaliknya, diagnosis diabetes mellitus tipe II meningkatkan resiko depresi pada seseorang atau bahkan membuat lebih parah seseorang yg telah menderita depresi. Hubungan ini mencerminkan 3 etiologi bersama yang terdiri dari interaksi dua arah yang kompleks mencakup beberapa variabel, antara lain disregulasi neurohormonal, obesitas, peradangan, perubahan struktur hipokampus (Semenkovich, Brown, Svrakic, \& Lustman, 2015)

Faktor psikososial yang mempengaruhi prevalensi depresi pada pasien diabetes, ternyata depresi pada diabetes mellitus tipe 2 lebih banyak dijumpai pada: perempuan, ras minoritas, seseorang yang tidak menikah pada umur pertengahan, status social, ekonomi rendah dan tidak bekerja(Degmecic Dunja, Bacun Tatjana, 2014). Sesuai dengan penelitian Schmitz (2016), dimana depresi semakin meningkat pada seseorang, sebagai akibat adanya faktor risiko seperti sosiodemografi, penyakit kronis, kurangnya komunikasi, dan kurangnya pengetahuan masayarakat maupun tentang depresi(Sears \& Schmitz, 2016).

Depresi merupakan salah satu masalah terbesar gangguan psikologis pada pasien diabetes mellitus tipe 2, dengan prevalensi antara $24 \%$ hingga 29\%. Depresi pada diabetes mellitus tipe 2 juga sangat berhubungan dengan ketidakmampuan mengkontrol glikemik, meningkatkan komplikasi, meningkatkan kematian, menurunkan fungsi fisik dan fungsi 
fikiran, dan meningkatkan biaya kesehatan(Starkstein et al., 2014).

Penanganan depresi pada penderita diabetes mellitus tipe 2 tampaknya kurang mendapat perhatian dibandingkan dengan komplikasi diabetes yang lainnya, untuk itu diperlukan suatu metode psikoterapi dalam membantu pasien diabetes mellitus dalam mengatasi depresi. Banyak metode psikoterapi yang dapat digunakan salah satunya adalah Spiritual Emotional Freedom Technique (SEFT).

SEFT merupakan sebuah metode yang menggunakan dasar sistem energi tubuh dalam menghilangkan masalah-masalah fisik maupun emosi secara cepat.mulai dari rasa takut, cemas, sedih, kecewa, stress, pobia, trauma, mentalitas kelangkaan dan penyakit psikologis lainnya serta masalah fisik seperti : mual, mules, sakit kepala berkepanjangan, epilepsi, stroke, jantung, kanker, dan lain-lain. SEFT merupakan sebuah gabungan dari S dan EFT. Lary Dosey sudah melakukan penelitian dan riset melalui jalur iilmiah bahwa doa dan spiritualitas memiliki efektifitas yang sama dengan operasi pembedahan, sedangkan EFT sendiri merupakan sebuah teknik revolusioner yang telah diciptakan untuk menghilangkan masalah emosi pertama kali. Namun perkembangan selanjutnya, ternyata EFT juga bisa untuk menghilangkan masalah fisik yang berhungan dengan tubuh kita.setelah diuji coba bahwa hanya dengan ketukan-ketukan ringan tersebut efektifitasnya untuk menghilangkan sakit fisik maupun emosi bisa mencapai $80 \%$.

Menurut Puspaningrum dan Wijayanti ( 2012) SEFT telah efektif dalam mengurangi tingkat stres pada pasien dengan penyakit kronis tetapi penelitian tentang SEFT sebelumnya belum pernah dilakukan dengan pasien gangguan jiwa.Berdasarkan studi pendahuluan yang di daerah wilayah kerja Singkawang Barat jumlah penderita Diabetes Millitus tahun 2017 sebanyak 1033 orang dan berdasarkan hasil wawancara dengan beberapa keluarga penderita diabetes millitus mengatakan bahwa rata-rata anggota keluarga yang mengalami luka ganggren dikaki sering termenung, kurang mau bicara, dan sering berdiam diri, akibatnya keluarg sulit untuk mengetahui apa yang dirasakan oleh pasien dan keluarga kurang memahami apa yang harus dilakukan untuk mengatasi masalah yang dirasakan oleh pasien. Terapi SEFT merupakan salah satu psikoterapi yang bisa diterapkan kepada masalah pasien dengan masalah psikososial, karena selain teknik tupping yang digunakan doa berpengaruh terhadap kekuatan seseorang dalam mengahadapi segala persoalan. Hal ini sejalan dengan penelitian yang dilakukan oleh Larry Dossey MD.adalah seorang doktor ahli penyakit dalam yang melakukan penelitian ekstensif tentang efek doa terhadap kesembuhan pasien. Penelitian yang sempat menarik perhatian dunia kedokteran barat ini dijelaskan secara rinci dan meyakinkan dalam bukunya The Healing Words: The Power of Prayer and The Practice of Medicine. Inti pesan yang ingin disampaikan oleh dokter Dossey adalah bahwa doa dan spiritualitas, terbukti dalam penelitian ilmiah, ternyata memiliki kekuatan yang sama besar dengan pengobatan dan pembedahan (Syafakallah,2009)

Berdasarkan studi pendahuluan yang di daerah wilayah kerja Singkawang Barat ada beberapa keluarga penderita diabetes millitus mengatakan bahwa rata-rata anggota keluarga yang mengalami luka ganggren dikaki sering termenung, kurang mau bicara, dan sering berdiam diri, akibatnya keluarg sulit untuk mengetahui apa yang dirasakan oleh pasien dan keluarga kurang memahami apa yang harus dilakukan untuk mengatasi masalah yang dirasakan oleh pasien. Terapi SEFT merupakan salah satu psikoterapi yang bisa diterapkan kepada masalah pasien dengan masalah psikososial, karena selain teknik tupping yang digunakan doa berpengaruh terhadap kekuatan seseorang dalam mengahadapi segala persoalan. Tujuan dari penelitian ini adalah untuk mengidentifikasi pemberian terapi Spiritual Emotional Fredoom Technique (SEFT) untuk mengurangi tingkat depresi pada pasien diabetes militus di Wilayah Kerja Pusat Kesehatan Singkawang Barat dengan jenis penelitian quasi eksperimen pre dan post without control.

\section{METODE}

Penelitian ini menggunkan kuisioner Beck Depression Inventory yang sudah digunakan oleh peneliti sebelumnya yang merupakan hasil modifikasi oleh peneliti sebelumnya dengan Beck Depression Inventory untuk mengukur tingkat depresi, sedangkan untuk melakukan SEFT menggunakan SOP yang sudah baku dengan versi lengkap. Penelitian ini sudah lulus uji etik dengan persetujuan komisi etik no 043/KEPK-PK.PKP/VIII/2018 Desain penelitian ini adalah kuasi eksperimen dengan pre dan post test without control. Penelitian ini dilakukan di 
wilayah kerja Puskesmas Singkawang Barat dari bulan Maret - Okteber 2018 dimulai dari persiapan, pelaksanaan sampai dengan analisis dan hasil penelitian.Populasi pada penelitian ini adalah seluruh pasien Diabetes Millitus yang berapa di wilayah kerja Singkawang Barat. Pemilihan sampel sesuia kriteria inklusi yaitu: pasien dengan DM tipe 2, Mengalami komplikasi, dapat membaca dan menulis, bersedia menjadi responden, teridentifikasi depresi. Pengambilan sampel dengan menggunakan Purposive sampling dengan jumlah sampel 35 responden. Setelah dilakukan pengambilan data hanya 25 responden yang didapat, ini karena alamat yang tidak lengkap, responden menolak dan ada yang sudah pindah rumah. Analisa ini bertujuan untuk mengetahui efektifitas Spritual Emotinal Freedom Technique pada Depresi pasien Diabetes Millitus, dengan mengukur pre dan post. Untuk menguji dua mean parametric pada kelompok yang sama digunakan Mc Nemartest.

\section{HASIL}

Karakteristik Responden

Tabel 1

Distribusi Karakteristik Penderita DM $(\mathrm{n}=25)$

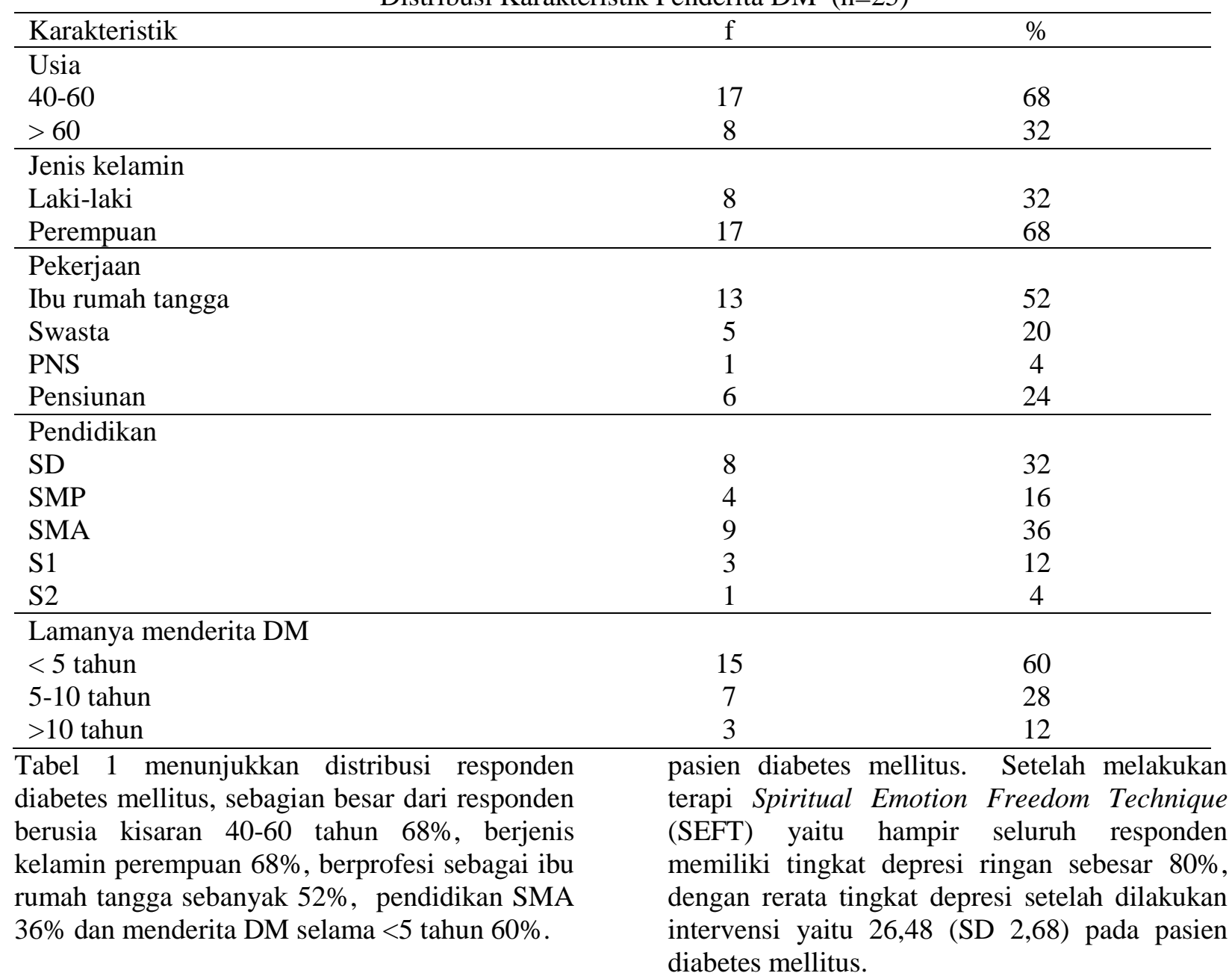

Gambaran Tingkat Depresi pada Pasien Diabtes Mellitus Sebelum Melakukan Terapi Spiritual Emotional Freedom Technique( SEFT)

Tabel 2 menunjukkan tingkat depresi responden sebelum responden melakukan terapi Spiritual Emotion Freedom Technique (SEFT) yang banyaki adalah memiliki tingkat depresi sedang 72 dengan hasil rerata tingkat depresi sebelum dilakukan intervensi yaitu 1,72 (SD 0,46) pada 
Tabel 2.

Tingkat Depresi Pada Pasien Diabetes Mellitus pre dan post Terapi Spiritual Emotional Freedom Technique $(\mathrm{SEFT})(\mathrm{n}=25)$

\begin{tabular}{|l|c|c|c|c|}
\hline \multirow{2}{*}{ Tingkat depresi } & \multicolumn{2}{|c|}{ Pre intervensi } & \multicolumn{2}{c|}{ Post intervensi } \\
\cline { 2 - 5 } & $\mathrm{f}$ & $\%$ & $\mathrm{f}$ & $\%$ \\
\hline Ringan & 7 & 28 & 20 & 80 \\
\hline Sedang & 18 & 72 & 5 & 20 \\
\hline Berat & 0 & 0 & 0 & 0 \\
\hline
\end{tabular}

\section{Efektifitas Terapi Spritual Emotional Freedom Technique (SEFT)Pada Depresi Pasien Diabetes Mellitus}

Tabel 3 menunjukkan analisis perbedaan nilai antara sebelum dan sesudah melakukan terapi Spiritual Emotion Freedom Technique (SEFT) pada responden yang dilakukan dengan McNemar
Test menghasilkan nilai probabilitas sebesar 0,000 ( $p$ value > 0,05), yang menunjukkan adanya perbedaan signifikan antara sebelum dan sesudah perlakuan pada pasien diabetes mellitus. Hasil analisis ini juga menunjukkan bahwa pemberian terapi SEFT dapat menurunkan depresi pada pasien diabetes mellitus.

Tabel 3

Analisis Tingkat Depresi Pada Pasien Diabetes Mellitus sebelum dan sesudah Pemberian Terapi Spiritual Emotional Freedom Technique (SEFT) $(\mathrm{n}=25)$

\begin{tabular}{|l|c|c|}
\hline Intervensi & Mean \pm SD & p \\
\cline { 1 - 2 } Pre & $32,28 \pm 5,11$ & 0,000 \\
\cline { 1 - 2 } Post & $26,48 \pm 2,68$ & \\
\hline
\end{tabular}

\section{PEMBAHASAN}

\section{Gambaran Kharakteristik Responden}

Distribusi umur responden menujukkan sebagian besar responden berusia 40-60 tahun (68\%) atau masih masuk kedalam usia produktif. Usia diatas 45 tahun lebih beresiko untuk terkena penyakit diabetes mellitus. Responden dengan kisaran 4060 tahun masih memiliki kekhawatiran pada masa depan dan masih mempunyai kewajiban untuk membesarkan serta membiayai sekolah anakanaknya namun terhalang oleh kesehatan tubuh akibat penyakit. Wulandari (2011) menjelaskan tingkat depresi tertinggi terjadi pada klien DM Tipe 2 dengan usia dibawah 60 tahun. Tingginya depresioner pada klien DM tipe 2 dibawah usia 60 tahun disebabkan oleh adanya kekhawatiran akan penghidupan di masa depan yang tidak menentu serta penurunan kesehatan tubuh, sedangkan pada klien DM tipe 2 yang berusia diatas 60 tahun telah memiliki rasa kepasrahan sehingga mampu menurunkan depresioner yang diterimanya akibat penyakit DM(Susilo, Y., \& Wulandari, 2011). Hal ini sejalan dengan penelitian yang dilakukan oleh Mufidah (2018), tentang gambaran tingkat depresi pada pasien diabetes mellitus dengan keluhan penyerta, bahwa mayoritas responden berumur $>60$ tahun (37\%)(Mufidah, 2018).

Penelitian ini melibatkan responden wanita lebih banyak (68\%) daripada responden pria (32\%). $\mathrm{Hal}$ ini dikarenakan responden wanita kemungkinan lebih ramah dan mempunyai keinginan sembuh yang tinggi. Adanya tanggung jawab untuk mengurus rumah dan keluarga, menjadi motivasi untuk mau melakukan terapi ini. Hal ini sesuai dengan hasil penelitian yang dilakukan Ramanda (2014) tetang gambaran tingkat depresi pasien diabetes mellitus tipe 2, dimana hasil penelitiannya $75 \%$ responden berjenis kelamin perempuan(Ramanda, Putrini, \& Irsan, 2014). Depresi sendiri prevalensinya dua kali lipat lebih sering ditemukan pada perempuan dibandingkan laki-laki. Penyebabnya antara lain dapat dibagi dari penyebab biologis dan psikososial yang membedakan antara laki-laki dan perempuan. Secara biologi, faktor hormonal meliputi siklus menstruasi, kehamilan, keguguran, pasca melahirkan menjelang menopause dan saat menopasu pada perempuan memegang peranan penting mengapa perempuan lebih rentan terhadap depresi dibandingkan laki-laki. Dari segi psikososial kaum perempuan memiliki tanggung jawab yang besar dalam mengasuh anak, selain itu perempuan juga memiliki kesempatan yang lebih kecil dalam mendapatkan pekerjaan yang digaji sebagai bentuk penghargaan atas kerja keras mereka. Faktor stressor psikososial memiliki efek yang sangat signifikan pada depresi(Ramanda et al., 2014).

Profesi yang paling banyak digeluti adalah ibu rumah tangga $(52 \%)$. Banyak hal yang dapat 
dikaitkan dengan pekerjaan seseorang, dimulai dari segi pendapatan sampai dengan aktivitas fisik yang dilakukan selama bekerja. Aktifitas fisik yang dilakukan oleh ibu rumah tangga relatif tinggi mulai dari memasak, mencuci, mebersihkan rumah dan lain sebagainya(Mufidah, 2018). Aktifitas banyak dan selalu monoton setiap hari serta keluhan yang sering muncul akibat penyakit serta keluarga menambah beban emosi sehingga ibu rumah tangga lebih rentan terkena depresi. Hal ini sesuai dengan penelitian yang dilakukan oleh Ramanda (2013) bahwa 55\% responden penelitian tentang tingkat depresi pasien DM tipe 2 adalah ibu rumah tangga.

Hasil penelitian ini didominasi oleh tingkat pendidikan Sekolah Menengah Atas (SMA) sebanyak 32\%. Mufidah (2018) menjabarkan tingkat pendidikan yang dimiliki oleh responden mebantu responden untuk memahami kondisi dirinya dan resiko yang dihadapi terkait dengan penyakit DM yang dideritanya. Responden yang banyak berpendidikan SMA dianggap mampu menerima saran tentang masalah kesehatan. Tingkat pendidikan juga berpengaruh dalam menerima informasi yang baru dan tidak memandang secara sebelah mata tekhnik / terapi Spiritual Emotional Freedom Tekhnik (SEFT) sehingga lebih mudah untuk melakukan pendekatan. Hasil studi longitudinal House, et al (1990) dalam Sutomo (2016) bahwa depresi mempunyai hubungan yang signifikan dengan kerusakan kognitif. Hal tersebut mengindikasikan bahwa bukan tingkat pendidikan seseorang yang menjadi prediktor depresi tapi ada kecendrungan ke aspek seberapa besar kerusakan kognitif yang dialami dan pengetahuan tentang penyakit(Sutomo \& Purwanto, 2016).

Lamanya menderita diabetes mellitus pada penelitian ini didominasi oleh kurun waktu kisaran 1-5 tahun. Reid \& Walker (2009) dalam Mufidah (2018) menjabarkan lamanya menderita diabetes mellitus juga berpengaruh terhadap keyakinan klien dalam perawatan yang tentunya berpengaruh pada kualitas hidupnya. Klien yang menderita DM > 11 tahun memiliki efikasi diri yang baik daripada kien yang menderita DM $<10$ tahun, hal itu disebabkan karena klien telah berpengalaman dalam mengelola penyakit dan meiliki koping yang baik(Mufidah, 2018).

\section{Gambaran Tingkat Depresi Pada Pasien Diabetes Mellitus Sebelum Dilakukan Spiritual Emotional Freedom Technique (SEFT)}

Diabetes mellitus merupakan penyakit gangguan metabolisme kronis yang ditandai peningkatan glukosa darah (Hiperglikemia), disebabkan karena ketidakseimbangan antara suplai dan kebutuhan insulin (Tarwoto W, Taufiq I, 2012). Kekurangan insulin dalam tubuh menyebabkan pasien diabetes mellitus harus menjalani pengobatan sepanjang sisa hidupnya supaya tidak mengalami efek yang lebih buruk karena komplikasi yang dapat ditimbulkan. Rasa bosan karena harus menjalani pengobatan, konsep diri yang terganggu karena tidak bisa berkerja seperti orang normal lainnya, putus asa karena tidak bisa sembuh dan kembali seperti sebelum terserang diabetes mellitus dan lain sebagainya dapat dialami oleh pasien diabetes mellitus. Kondisi kejiwaan yang tidak tenang karena terserang penyakit dan secara terus menerus merasa tertekan dapat menyebabkan pasien diabetes mellitus mengalami depresi.

Menurut Kusnadi Jaya (2015), depresi adalah suatu kelainan alam perasaan yang berupa hilangnya minat atau kesenangan dalam aktifitas yang biasa dan pada waktu yang lampau. Tingkat keparahan depresi secara mayor dikategorikan menjadi depresi ringan, sedang dan berat(Kusnadi, 2015). Pada hasil penelitian ini tingkat depresi pasien diabetes mellitus sebelum dilakukan terapi Spiritual Emotion Freedom Technique (SEFT) yaitu sebanyak 18 responden (72\%) mengalami depresi sedang dan 7 responden (28\%) mengalami depresi ringan. Hasil penelitian ini sejalan dengan hasil penelitian yang dilakukan oleh Reini Astuti (2015), sebelum dilakukan terapi Spiritual Emotion Freedom Technique (SEFT) pada pasien HIV kelompok intervensi yaitu sebanyak 3 responden (20\%) mengalami depresi berat, 7 responden $(46,7 \%)$ mengalami depresi sedang, dan 5 responden $(33,3 \%)$ berada di garis batas depresi klinis.

Menurut kriteria ICD-10, Gejala depresi sedang meliputi 2 gejalan utama ditambah 3 gejala atau lebih gejala lain. Gejala utama seperti mood depresi yang terjadi sepanjang hari atau bahkan setiap hari dan hilangnya minat atau kesenangan secara jelas dalam semua atau hampir semua, aktivitas sepanjang hari atau hampir sepanjang hari. Dan 3 gejala lain seperti peningkatan / penurunan nafsu makan yang disertai / tidak disertai peningkatan berat badan, insomnia, cepat lelah dan lain-lain.

Pada penelitian ini gejala yang selalu dan sering dialami oleh responden adalah perasaan sedih dan tidak bahagia, kesulitan untuk bekerja, insomnia dan sering terbangun dimalah hari, merasa lelah untuk melakukan apapun serta tidak mempunyai selera makan. Gejala-gejala tersebut membuktikan 
bahwa responden menderita depresi dengan tingkat kategori sedang karena menderita penyakit diabetes mellitus. Kriteria ICD-10 untuk gejala depresi ringan meliputi 2 gejala utama ditambah 2 gejala lain. Gejala-gejala seperti perasaan tidak bahagia, ingin bunuh diri, insomnia dan gejalagejala lain jarang ditunjukkan oleh pasien diabetes mellitus. Gejala-gejala tersebut membuktikan bahwa responden mengalami depresi ringan.

\section{Gambaran Tingkat Depresi Pada Pasien Diabetes Mellitus Sesudah Dilakukan Spiritual Emotional Freedom Technique (SEFT)}

SEFT adalah sebuah metode yang menggunakan dasar sistem energi tubuh dalam menghilangkan masalah-masalah fisik maupun emosi secara cepat. mulai dari rasa takut, cemas, sedih, kecewa, stress, pobia, trauma, mentalitas kelangkaan dan penyakit psikologis lainnya serta masalah fisik seperti : mual, mules, sakit kepala berkepanjangan, epilepsi, stroke, jantung, kanker, dan lain-lain (Faiz Zainudin, 2009).

Hasil penelitian ini didapatkan data setelah melakukan terapi SEFT selama 7 hari, responden dengan tingkat depresi sedang hampir semuanya mengalami penurunan menjadi depresi ringan yaitu sebanyak 20 responden $(80 \%)$ mengalami depresi ringan dan hanya 5 responden (20\%) yang mengalami depresi sedang. Hasil penelitian ini sejalan dengan penelitian yang dilakukan oleh Astuti (2015), setelah dilakukan terapi Spiritual Emotion Freedom Technique (SEFT) pada pasien HIV kelompok intervensi yaitu sebanyak 8 responden $(53,3 \%)$ mengalami gangguan mood, 2 responden $(13,3 \%)$ mengalami depresi sedang, dan 5 responden $(33,3 \%)$ berada dalam batas wajar(Astuti, Yosep, \& Diah Susanti, 2015).

Gejala-gejala yang sering dikeluhkan responden seperti perasaan lelah untuk melakukan apapun, insomnia dan penurunan nafsu makan, jarang bahkan tidak pernah dikeluhkan oleh responden. Namun responden yang masih mengalami depresi sedang, mereka memang masih mengalami gejala utama dan gejala-gejala lainnya namun dengan intensitas yang sering bahkan jarang dialami. Faktor seperti intensitas waktu dan seringnya melakukan terapi SEFT dalam setiap harinya juga dapat menjadi faktor penentu berhasilnya responden dalam menurunkan tingkat depresinya.
Tingkat Depresi Pada Pasien Diabetes Mellitus Sebelum dan Sesudah Dilakukan Spiritual Emotional Freedom Technique (SEFT) Pada Kelompok Intervensi

Hasil uji statistik dari penelitian ini menunjukkan bahwa dari hasil penelitian terhadap efektifitas Spiritual Emotion Freedom Technique (SEFT) terhadap tingkat depresi pasien diabetes mellitus di Singkawang Barat pada tahun 2018 didapatkan hasil yang menujukkan adanya penurunan tingkat kategori depresi responden yang awalnya mengalami depresi sedang menjadi depresi ringan setelah melakukan terapi SEFT tersebut dengan nilai probabilitas sebesar 0,000 ( $p$ value $>0,005$ ). Hasil penelitian ini sesuai dengan hasil penelitian Bakara (2013), yang menyatakan intervensi SEFT membantu menurunkan depresi, kecemasan dan stres pada pasien Sindrom Koroner Akut (SKA).

SEFT merupakan gabungan dari Spritual dan Emotional Freedom Technique. S merupakan akronim dari spiritual, kita ketahui spritualitas dianak tirikan didalam dunia kedokteran. Namun dokter dari Amerika berkata lain Larry Dosey melakukan penelitian melalui jalur ilmiah bahwa doa dan spritualitas memiliki efektifitas yang sama dengan operasi pembedahan. Sedangkan EFT sendiri merupakan teknik yang diciptakan untuk menghilangkan emosi pertama kali. Perkembangannya EFT juga bisa menghilangkan masalah fisik yang berhubungan dengan tubuh kita. Setelah diuji coba dengan ketukan-ketukan ringan tersebut efektifitas untuk menghilangkan sakit fisik maupun emosi mencapai $80 \%$ (Faiz Zainudin, 2009).

Terapi farmakologis memang terbukti dapat mengendalikan gula darah agar tetap dalam batas normal. Namun terapi farmakologis untuk penderita diabetes mellitus tidak dapat menurunkan kecemasan dan depresi akan penyakit yang diderita. Fisik bisa terobati namun psikologis / kejiwaan penderita diabetes mellitus tidak dapat terobati dengan ragam terapi farmakologis yang diresepkan oleh dokter penyakit dalam. Maka dari itu dibutuhkan terapi SEFT ini. Ketukan-ketukan ringan sebanyak 3 kali yang dilakukan pada 18 titik tubuh diiringi dengan do'a serta perasaan pasrah dan ikhlas atas penyakit yang diderita serta permintaan untuk kesembuhan terbukti dapat menurunkan tingkat depresi responden.

Diawali dengan The set up yang bertujuan untuk memastikan agar aliran energy tubuh kita terarahkan dengan tepat. Langkah ini untuk menetralisir psychological reversal atau perlawan 
psikologis)biasanya melawan pikiran negative spontan atau keyakinan bawah sadar negative. Kemudian dilanjutkan dengan the tune in. Untuk masalah fisik, kita melakukan tune-in dengan cara merasakan rasa sakit yang kita alami, lalu mengarahkan pikiran kita ke tempat rasa sakit, dibarengi dengan dengan hati dan mulut kita berdo'a serta untuk masalah emosi, kita melakukan " Tune-In" dengan cara memikirkan sesuatu atau peristiwa spesifik tertentu yang dapat membangkitkan emosi negative yang ingin kita hilangkan. Pada proses inilah (Tune -in bersamaan dengan tapping) kita menetralisir emosi negative atau rasa sakit fisik. Terakhir adalah tapping, tapping adalah mengetuk ringan dengan 2 ujung jari apada titik-titik tertentu ditubuh kita sambil terus tune-in. titik-titik ini adalah titik kunci dari " the major energy meredians", yang jika kita ketuk beberapa kali akan berdampak pada ternetralisirnya gangguan emosi atau rasa sakit yang kita rasakan, karena aliran energy tubuh berjalan dengan normal dan seimbang kembali.

Zainuddin (2012) dalam Etika (2016), efektifitas SEFT tersebut dikarenakan oleh SEFT mempunyai penekanan pada kepasrahan dan keikhlasan pada Tuhan serta tapping pada beberapa titik akupuntur yang dapat meberikan perasaan rileks bagi tubuh. Halm (2009) dalam Bakara (2013) menyebutkan terapi spiritual berpengaruh terhadap aktivitas sistem saraf simpatis, dampak dari relaksasi tersebut pernapasan menjadi lebih lambat iramanya, nadi lambat, tekanan darah turun, menurunkan konsumsi oksigen otot jantung dan ketegangan otot. Respons relaksasi juga berpengaruh pada konsisi mental dan menurunkan ketegangan otot sehingga menimbulkan suasana yang nyaman, dapat menurunkan stres juga mempengaruhi interaksi dari psychoneuroendocrine.Syed (2003) dalam Bakara (2013) menyebutkan terapi spiritual menimbulkan respons relaksasi dan kesehatan, dapat menimbulkan keyakinan dalam perawatan diri, dan bermanfaat terhadap kecemasan dan panik pasien terminal yang dapat menimbulkan ketenangan(Marsinova Bakara, Ibrahim, \& Sriati, 2013).

Keefektifan terapi SEFT juga dipengaruhi oleh kefokusan serta intensitas melakukan terapi dalam kurun waktu 7 hari. Responden dengan intensitas waktu 1-2 kali per hari dengan responden yang 57 kali per hari melakukan terapi terdapat perbedaan. Perasaan tenang dan nyaman lebih banyak diutarakan oleh responden yang melakukan terapi 5-7 kali per hari sedangkan perasaan biasa-biasa saja banyak di utarakan oleh responden yang melakukannya 1-2 kali per hari. Tujuan lain yang telah tercapai dari penelitian ini adalah semakin dekatnya responden dengan sang pencipta dan meningkatkan keimanan karena terapi ini menyisipkan lantunan do'a yang dapat memberi ketenangan jiwa sesuai dengan kepercayaan responden masing-masing. Hasil diatas dapat disimpulkan bahwa terapi SEFT dapat menurunkan tingkat depresi dari yang depresi sedang ke depresi rendah pada pasien Diabetes Millitus Tipe II.

\section{SIMPULAN}

Penelitian dapat disempulkan bahwa pemberian terapi SEFT dapat mengurangi depresi pada pasien dengan diabetes mellitus di wilayah Puskesmas Singkawang Barat.

\section{DAFTAR PUSTAKA}

Astuti, R., Yosep, I., \& Diah Susanti, R. (2015). Pengaruh Intervensi SEFT (Spiritual Emotional Freedom Technique) terhadap Penurunan Tingkat Depresi Ibu Rumah Tangga dengan HIV. Jurnal Keperawatan Padjadjaran. https://doi.org/10.24198/jkp.v3n1.6

Degmecic Dunja, Bacun Tatjana, K. V. (2014). Depression, Anxiety And Cognitive Dysfunction In Patients With Type 2 Diabetes Mellitus - A Study Of Adult Patient With Type 2 Diabetes Mellitus In Osijek, Croatia. 2, 711-716.

Dinas Kesehatan Republik Indonesia. (2013). Riset Kesehatan Dasar. Diabetes Mellitus. https://doi.org/1 Desember 2013

Faiz Zainudin, A. (2009). Spiritual Emotional Freedom Technique (SEFT). Surabaya: Logos Institute.

Kusnadi, J. (2015). Keperawatan Jiwa. Tanggerang: Binarupa Aksara Publisher.

Marsinova Bakara, D., Ibrahim, K., \& Sriati, A. (2013). Efek Spiritual Emotional Freedom Techniqueterhadap Cemas dan Depresi, Sindrom Koroner Akut. Jurnal Keperawatan Padjadjaran. https://doi.org/10.24198/jkp.v1n1.6

Mufidah, S. (2018). Gambaran Tingkat Depresi Pada Pasien Diabetes Melitus Dengan Keluhan Penyerta Di RSUD DR. Moewardi Surakarta. Ums. 
Ramanda, R., Putrini, ; Jojor, \& Irsan, ; Abror. (2014). Gambaran Tingkat Depresi Pasien Diabetes Melitus Tipe 2 Di Puskesmas Purnama Pontianak Tahun 2013.

Sears, C., \& Schmitz, N. (2016). The Relationship between Diabetes and Mental Health Conditions in an Aging Population. Canadian Journal of Diabetes. https://doi.org/10.1016/j.jcjd.2015.11.007

Semenkovich, K., Brown, M. E., Svrakic, D. M., \& Lustman, P. J. (2015). Depression in type 2 diabetes mellitus: Prevalence, impact, and treatment. Drugs, 75(6), 577-587. https://doi.org/10.1007/s40265-015-0347-4

Starkstein, S. E., Davis, W. A., Dragovic, M., Cetrullo, V., Davis, T. M. E., \& Bruce, D. G. (2014). Diagnostic criteria for depression in type 2 diabetes: A data-driven approach. PLoS ONE. https://doi.org/10.1371/journal.pone.01120 49

Susilo, Y., \& Wulandari, A. (2011). Diet Sehat Untuk Penderita Diabetes Melitus. Yogyakarta: ANDI Yogyakarta.

Sutomo, N., \& Purwanto, F. (2016). Efektifitas Teknik Seft (Spiritual Emotional Freedom Technique) Terhadap Peningkatan Kualitas Hidup Pada Pasien Pasca Stroke. Jurnal Keperawatan, 9(2), 01-08. Retrieved from https://jurnalkeperawatan.lppmdianhusada.a c.id/index.php/jk/article/view/28

Tarwoto W, Taufiq I, M. L. (2012). Keperawatan medikal bedah gangguan sistem endokrin. Jakarta: TIM.

WHO. (2011). Definational and diagnosis of diabetes mellitus and intermedia hyperglikemia.

WHO. (2013). Definational and diagnosis of diabetes mellitus and intermedia hyperglikemia. 
Jurnal Keperawatan Jiwa Volume 8 No 2 Hal 129 - 138, Mei 2020

FIKKes Universitas Muhammadiyah Semarang bekerjasama dengan PPNI Jawa Tengah 